\title{
妙高高原町に発生した土石流災害について
}

\section{1. 発生概況}

5 月 18 日午前 6 時 20 分頃に新潟県中頸城郡妙高村の妙 高山（標高 $2,446 \mathrm{~m}$ ）の外輪山にあたる, 赤倉山中腹て 二度にわたって崩壞が発生した。 1 回目は午前 6 時 20 分 頃, 2 回目は午後 1 時 40 分頃である。場所は関川支流白 田切川の左岸で，標高 $1,600 \mathrm{~m}$ 付近（昭和46年大晦日に 発生した南地獄谷地すべり地点より, 距離で $300 \mathrm{~m}$ 程離 れている) の北東斜面で迎三角形を型どる尾根に狭まれ た地点, すなわち, 谷型地形をした地点で発生している。 崩れ出した土塊は土石流となり白田切川沿いに流下し, 山麓に広がり新赤倉温泉を襲い，さらに白田切分岐点の 締切堤を破壞し国道18号線架橋の橋脚の基礎部を洗掘し， 交通に支障をきたし，国鉄信越線の路床を直撃流出せし め，線路を宙づりにさせ土砂は関川に達した。

崩壊発生地点より関川までの区間で土石流の特徽を遺 憾なく発揮しその延長は約 $7.5 \mathrm{~km}$ に達した。

崩壊土量は約 $300,000 \mathrm{~m}^{3}$ とみられ, 被害面積は約 45 ha, 堆積土砂量は約 $650,000 \mathrm{~m}^{3}$ 程度と推定される。ま た゚，上方部には土塊が不安定な状態で残存しており，そ れらを含めて，流出土砂量の把握は今後の調查をまたな ケれぱ判明しない。

土石流の規模は, 従来の規模からみて非常に大きく, 速度は第 1 回のとき約 $20 \mathrm{~m} / \mathrm{sec}$ ，第 2 回のときで約 17 $\mathrm{m} / \mathrm{sec}$ 程度と推定される。
白 石一 夫

図- 1 に崩壊発生箇所から関川への 合流点までの 平面 図を示した。これにより，各区間別に概略の縦断勾配を 久る。崩壊土塊の滑落斜面勾配は約 $60^{\circ}$ で，治山区間ま での平均勾配は約 $20^{\circ}$ ，この中には垂直に流れる渲もい くつかある。また, 砂防区間での平均勾配は約 $7^{\circ}$, 氾

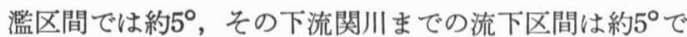
ある。つぎに，各区間別での地形と図上に示した流下幅 線をみると，流下幅の等しい所では谷が深くなっており， 堆積土砂より洗掘土砂量が多いと思われる。区間で示す と, 新赤倉の氾濫区間上流と白田切川分岐点下流にみら れる。それに比べ，氾濫区間では谷は浅く，等高線をみ ても左右岸は浅い沢状を示している。

図- 2 に今回の土石流で最も被害が大であった新赤倉 温泉地区に拈ける，土石流の流下区間，堆積区間および 被害家屋を印した平面図を示す（図-1の氾濫区間に該 当する)。戝中の矢印は全壞家屋が流された方向を示す。 平面図あるいは写真から明らかなように, 土石流の直進 傾向がみられる。

\section{2. 南地獄谷付近の地質}

同地域は，第 4 紀初期に起った火山活動によって，外 輸山の火山岩類等を噴出し, 後ち外輪山の中央部で陥没 が生じ，カルデラ湖が大規模に形成された。これにより 湖沼准積物の火山灰 - 火山砂・泥岩等は堆積されたもの と考えられ，再びカルデラ湖の周辺をつきやぶって石英
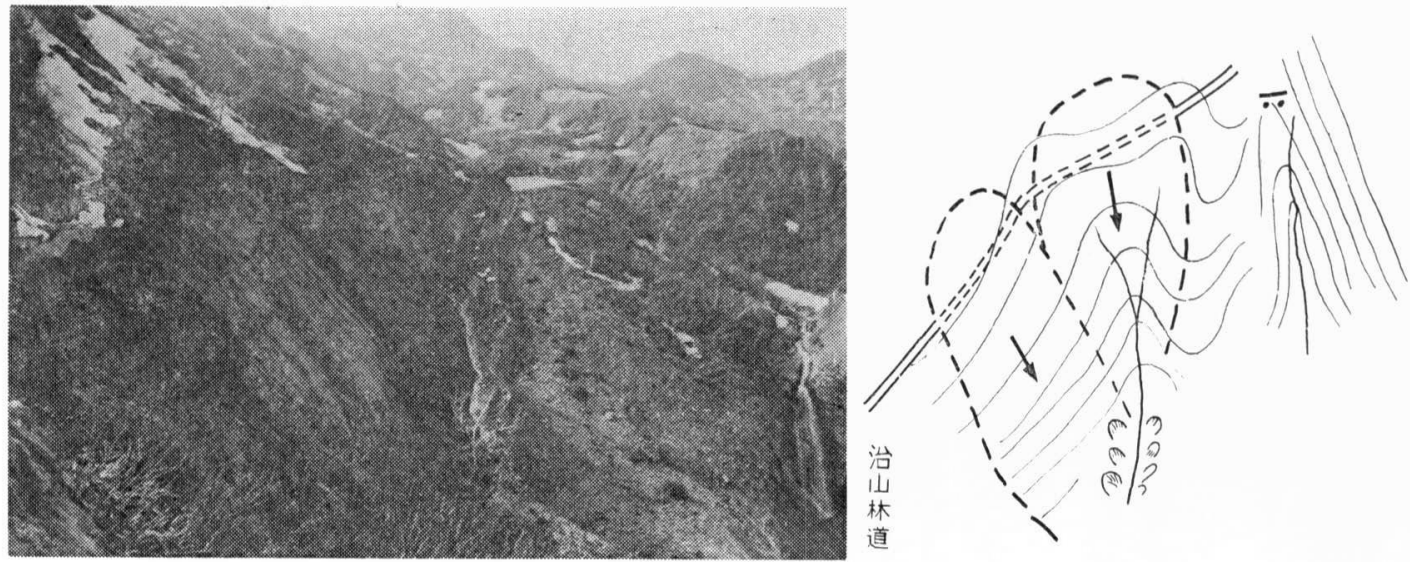

写真-1 土石流となった山腹崩壞地（源頭部）

* 建設省土木究所新潟試験所 


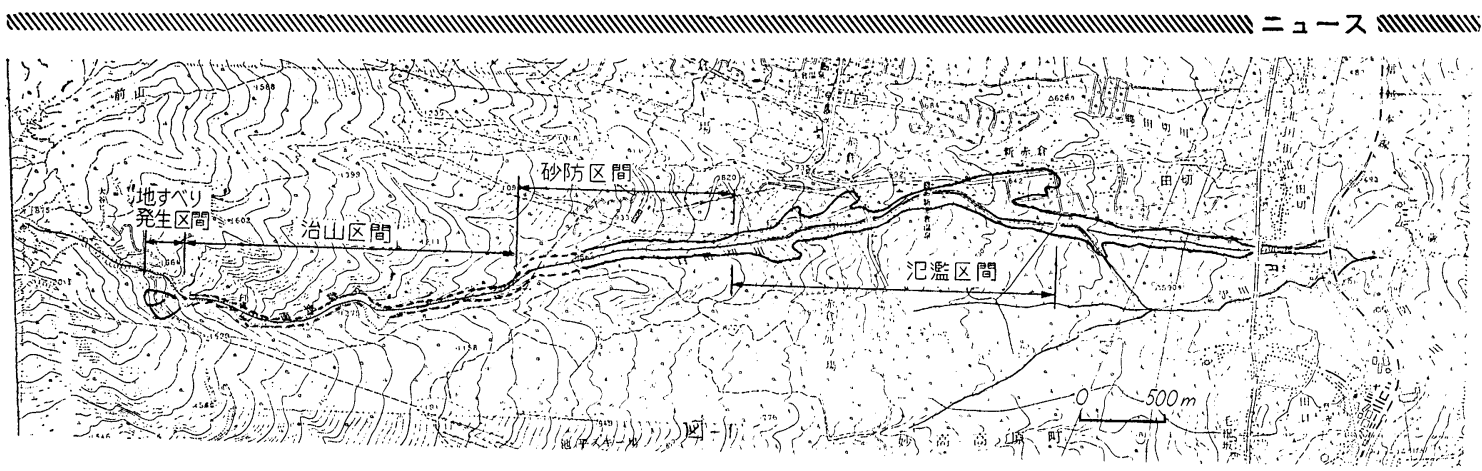

図-1

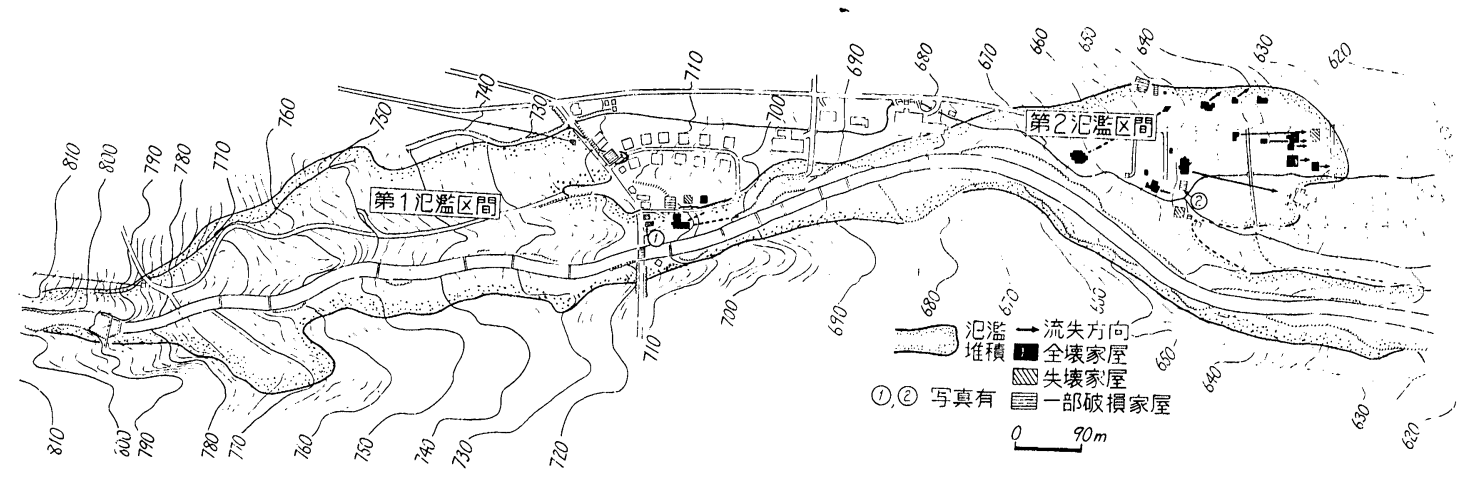

図-2 氾濫区間

安山岩質の岩石を噴出し, 妙高山がつくられたが, 引続 き小爆発が起り, 小規模な爆裂火口が形成され, 北地獄, 南地獄がつくられたと推察されている。

\section{3. 崩壊発生前の気象}

妙高高原町頸南消防署で観測された気象データーをも とに 52 年，53年の消雪日，気温を比較する。まず消雪日 をみると 52 年は 4 月 10 日だが53年は 4 月 19 日で 9 日程度 雪消えが遅れている（崩壊箇所付近において 1 週間後で も沢地で積雪がみられた)。また, 日平均気温をみると, 52 年 3 月では 5 以下の日が 20 日に対し，53年 3 月は 27 日, また 52 年 4 月の $10^{\circ}$ 以下の日数は 13 日に対し 53 年. 4 月は 18日であった。また，災害発生日までの 5 月の日平均気 温で比較すると, 52 年 5 月は $10^{\circ}$ 以下 1 日, $10.1^{\circ} \sim 15^{\circ}$ 12 日, $15.1^{\circ} \sim 20^{\circ} 3$ 日, $20.1^{\circ}$ 以上 1 日それに対し53 年 5 月では $10^{\circ}$ 以下 $0,10.1^{\circ} \sim 15^{\circ} 7$ 日, $15.1^{\circ} \sim 20^{\circ}$ 7 日, $20^{\circ}$ 以上 3 日であった。特に, 㷋害発生前の 6 日 間は最高気温 $20^{\circ}$ 以上を記録し，特に前日は $29.5^{\circ}$ を記 録, その前 3 日間は $27.5^{\circ}$ であった。これらの值からみ ると崩壊発生箇所において気温が $20^{\circ}$ を越えたことも考 えられ，融雪がかなりあったものと思われる。

\section{4. 施設等の被害状況}

今回の土石流による被害

\section{【土石流}

一次, 二次災害合せて崩壊土量約 30 万 $\mathrm{m}^{3}$, 堆積土砂 量約 65 万 $\mathrm{m}^{3}$

[人的被害]

死者 13 人, 負傷 1 人

〔建物被害?（住宅, 寮, 別荘のみ)

全壊 13 棟, 半壊 6 棟, 一部破損 8 棟

〔道路〕

土砂による埋没 旧国道約 $100 \mathrm{~m} ， 30 \mathrm{~m}$ 区間流出 県道 約 $600 \mathrm{~m}$

[橋梁]

国道 $1 \cdots \cdots$ 橋脚一洗掘

町道 $1 \cdots \cdots \cdot$ 流出

〔農地〕

土砂に埋まった農地 $\quad 0.6$ ha

土砂に埋まった用水路 $3 \mathrm{~km}$

水の入らなくなった農地 $19.4 \mathrm{ha}$

[その他]

河川, 砂防構造物等

電柱折摃

スキーリフト

温泉バイブの破損

図-1の平面図に示した，氾濫区間の上流にあたる治 山，砂防区間，また下流にあたる白田切川分岐点下流で 


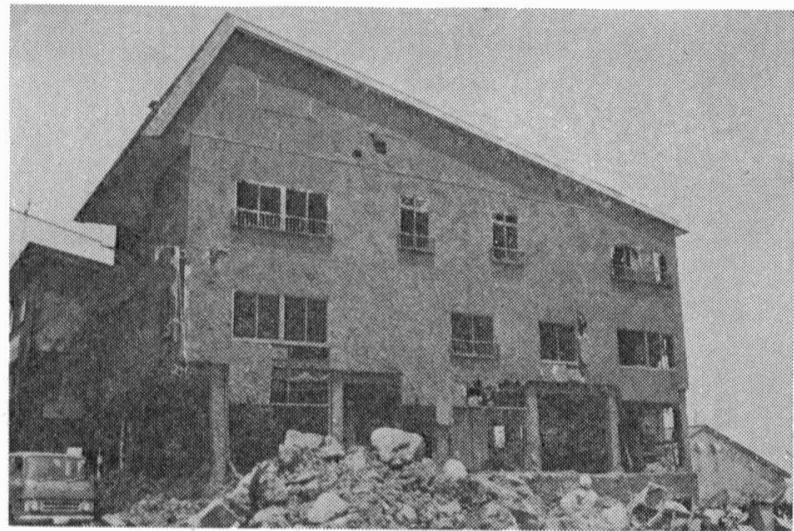

写真-2 図-2の(1)半壊家屋

土台から高さ $8 \mathrm{~m}$ の地点に飛石による破損がみられる。また，左側 手前の $30 \mathrm{~cm}$ 角鋼材の 柱が曲がっている。建物手前の石の山は家屋 に飛び込んだもの（縱横 $2.4 \mathrm{~m}$ 程のむのむ入っだを取り出し割の たものである

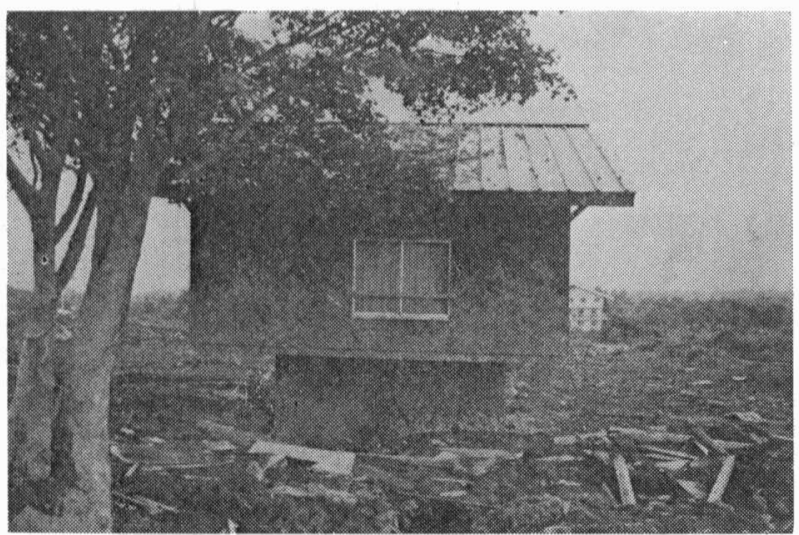

写真-3 汹-2の(2

第 2 氾監区間の汪活中央に位置する家屋。土台が鉄筋コンクリートて 基礎の高い家では、被害は一部損傷

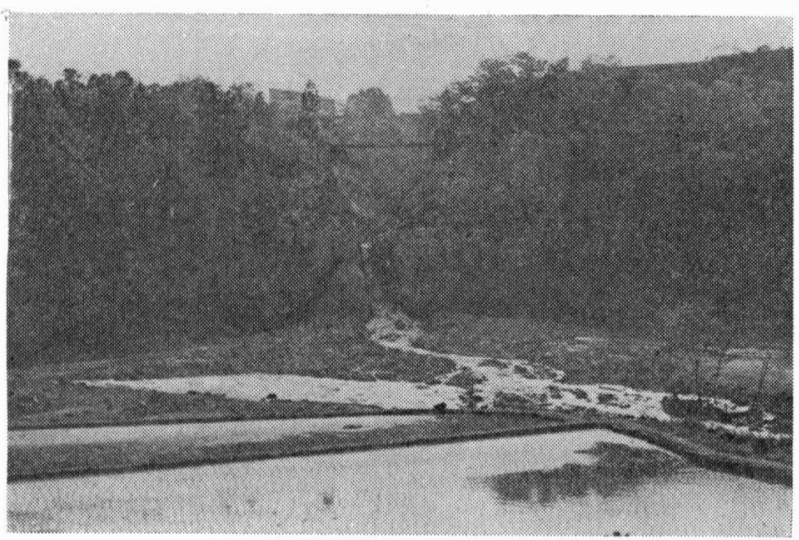

写真-4 信越線の路床の流失と関川にみられる砂䃯円錐
は谷が深く溪谷となっている。それに比へ，新赤 倉温泉地域の汇濫区間では谷は浅く, 堆積地域側 の等高線は流心に, ほぼ直角の向きでみられ, 堆 積地の縱断勾配は平均 $5{ }^{\circ}$ である。そして，その氾 濫区閒の堆積地は白田切川左岸に集中し, 2 力所 もっている。1 カ所は赤倉観光ホテルゴルフ場で, 溪谷を蛇行しながら流下した土石流は，開けたゴ ルフ場で蓄積されてきたエネルギーを解放し，延 長の長い扇状に広がりをみせ, その先端は町道に 沿って建ら亚ぶ家屋の一部に被害を与克停止した。 その面積は約 14 万 $\mathrm{m}^{2}$ 。一方, 白田切川上を流下 した土石流は左岸の家屋 2 軒を半壊 (写真- 2 ) さ せ, その家屋の裏手にある家屋 2 棟を全壊させ他 の 2 棟に被害を与克,さらに下流へと流下した。 もら 1 力所の氾濫区間は, 開発めざましい新赤倉 の別荘地を直撃した。その面積は約 26 万 $\mathrm{m}^{2}$ 。こ の区間における住宅被害が最も大で全壞10棟, 半 壊 2 棟, 一部被害 3 棟を数学る (図- 2 参照)。図 上に全壊家屋のおよその流下方向と流下距離を示 した。

建造物被害の状況からも土石流エネルギーの強 大さをまざまざとみせつけられた。また，一部の 建物で高さ $8 \mathrm{~m}$ の所の石高ボードが飛石により穴 をあけられた被害の痕䟢がみられた（写真-2）。

また, 白田切川分岐点では人工的に本流とした 深沢川* への流下は汪とんどみられず，土石流の 特徵である直進性とその内部に秘められたェネル ギーにより，白田切川に設けられた締切堤を打ち 破り, 昔ながらの白田切川の奖谷を流下した。そ して, 旧国道を $30 \mathrm{~m}$ にわたり洗掘流出せしめ, 国道18号線架橋の橋脚の基礎を洗掘し, 橋梁を危 険な状態とし, さらに信越線の路床を破壊し（写 真-4）関川へと流下した。

* その昔, 白田切川は真っすぐ流れていた。それが，明治21年 国鉄信越線の開通の際, 溪谷であった白田切川を管渠とし, その上部を土で成り上げ路床とする計画となり, 白田切川, 樑沢川の分岐点で本流であった白田切川に楴切堤を設け，流 れを人工的に深沢川に移した。 